\title{
Corporate Financing in Romania
}

\author{
Sebastian Bodu \\ Ph.D., MBA, Romanian-American University, Bucharest, Romania, bodu.sebastian@gmail.com
}

\begin{abstract}
Two are the external sources of corporate financing: equity and debt. These are exclusive (other sources of external financing no longer exist, but only variants thereof) and can be combined in turn. Capital with which a company is financed is its engine, no company being able to operate without capital regardless of the industry. Funding may be private or public. Private financing is provided through banking credit or equity contracted through direct negotiation with investors. Each mode of financing has advantages and disadvantages, not only in terms of financial costs (direct) but also indirect costs. Internal funding source is self-financing, i.e. reinvesting the company's profit instead of distributing it in the form of dividends. Balancing the use of internal and external financing sources, as well as the share of an external source in relation to another external source, primarily depending on the cost of financing (direct or opportunity) is a difficult, important and complex decision. The more the company is and / or the more attractive for investors, the more varied the range of financing options and the cost structure that is heavily influenced by rating agencies. Conversely, a small company without too many development prospects will not have access to all available sources in the market and will have to confine itself to small bank loans. Corporate contributions can be in cash, in kind, in debt and in services. They constitute the common fund that the shareholders exploit under the umbrella of the legal personality of the company. From a legal point of view, contributions become property of the company (assets) and it dispose of them as it deems necessary by spending, selling or mortgaging. In order to be valid, the contributions must fulfill several conditions. In all cases, the contributions must be real, fictitious inputs being forbidden. Apart from the reality of contributions, they must also be useful to company. In exchange for its contribution, the shareholder receives shares incorporating rights, which for a shareholder or future shareholder interested in his investment is the share of legal capital or, in other words, the share of the legal capital represented by his shares in the company. The second form of external financing, credit, may be private or institutionalized. Institutionalized credit is an interest-rate loan granted by a financial institution such as a bank, an investment fund, or a nonbanking financial institution. In practice, funders put conditions for the funded company in relation to its shareholders, managers or assets, so as to avoid changes that would risk reimbursing the credit. The statute of limitation of the right to request repayment of the credit is within three years of the maturity date, and in the case of successive loans between the same parties, a separate term will begin to run for each loan. The repayment of credits granted in a given currency must be made in the same currency, regardless of the increase or decrease of the value of the respective currency against other currencies (the monetary denomination rule). To hedge foreign exchange risk, some companies resort to hedging through options on the foreign exchange market in the form of risk transactions in the opposite direction to that assumed by the contracted loan.
\end{abstract}

KEYWORDS: contributions, company, corporate finance, currency, debt, dividends, equity, loan, profit, statute of limitation

\section{Corporate finance sources}

It is known that the "engine" of an enterprise is capital. It can come from different sources, either in the form of equity or in the form of debt (Dimitriu 1902, 249). As a consequence, managing the financing sources is a vital issue for the functioning of a company, in the absence of such sources, the company being unable to obtain the necessary resources to carry out its activity. A company has a choice of several funding options from the two source forms. Once the funding has been procured, attracted amounts turn into resources, i.e. assets that are used in revenue generating operations. The fundamental objective of a company is to maximize the wealth of its shareholders, that is to say, the fair market value of the company, and, therefore, all the shares issued and held (Prunea 2001, 281). In order to do this, the company must develop its operations, grow as a business, and for this purpose it needs investment to be financed either from the two sources - equity and debt - also called external financing sources, or selffinancing, also referred to as a source of internal funding, as well as a combination of these. 
The two types of external financing source - equity and debt - are exclusive (other sources of external funding no longer exist but only variants) and can be combined in turn. Funding through new contributions can be done through equity (ordinary shares, preference shares, convertible preferred shares). Debt financing can be done by banks loans, loans from other financial institutions, shareholders or any third party willing to finance the company, including through the issuance of simple or convertible bonds, or it can be done in the form of leasing or credit-supplier (Popa, et. al. 1997, 407) (financing by convertible into share capital is called mezzanine finance). Of all these, bank loans are the largest share in the domestic and European-continental economy (Prunea 2001, 266), as opposed to the US and UK markets where the issuance of financial instruments prevails. Even in the United States or the United Kingdom, issues of financial instruments are, however, specific to large, listed companies, the smallest and medium-sized ones, usually resorting to institutional loans as well (Bank of England, Quarterly Bulletin 2018 Q1).

Regardless of source - equity or debt - funding may be private or public. Attracting an investor to subscribe new shares issued by the company or taking a debt are the private forms of financing. Public form is the way to attract financing from the capital market through the issuance of financial instruments in the form of a public offering, in which case, in addition to the provisions of the general law or the company's law on the operation, the capital market regulation apply to protect the investors. Each model of financing has advantages and disadvantages, not only in terms of financial costs (direct) but also indirect costs. Indirect costs are compliance with the securities regulation regarding both reporting and transparency requirements, as well as the rules of the stock exchange where its securities are traded. But perhaps even more indirect costs are the loss of control over voting rights in the company as a result of dilution of initial shareholders. The advantage of listing is, first of all, the liquidity of the market on which the securities traded, investors being able any time convert their investment in cash at the market price, which makes the investment in securities a more secure than the investment in the stock of a closed-end company.

Accounting records are based on the source of funding and the liquidity of the debt resulting from financing, with a synthetic accounting account specifically allocated to that form of finance, accounts in the same class or in different classes. If the company has unpaid shares from a previous issue, calling for debt to finance is the only option (Stelian 1916, II, 273). From the investor's point of view, the financing of the company must be attractive, i.e. it should have a better return than another similar financing opportunity. A funny example is the issuance of bonds denominated in hard currency by a Russian vodka producer paying an interest of $20 \%$ p.a. or $25 \%$ in vodka. According to the bidder, "vodka is used as a 1000-year exchange currency" (Higgins 1996, 146).

Financing from internal sources (or self-financing) means reinvesting the company's profit instead of distributing it in the form of dividends (Băcanu 1999, 134; Pătulea 2009, 276), which implies that the shareholders give up their share of net profit, capitalizing on the company and increasing its value, starting with the accounting one (net assets). This is quite rare, with only very profitable companies being in the position of not resorting to external sources, and that, as I said, is due to the reduction or suppression of dividends (Apple, Inc., for example, had a policy of retaining and reinvesting all profits by 2012 that allowed it to self-finance). Self-financing therefore means buying money for investments (buying assets) from its own corporate operations, money that, if distributed as dividends in full, would be to the detriment of the capitalization of the company, which would, from the point of view of financial view - not accountant (Oroviceanu 2010, 65) - a decapitalization. Increasing the value of a company means increasing the value of shares, and such an increase has a twofold consequence: (i) improving the financial ratios of the company and (ii) reducing the cost of financing from sources external. However, if the company's investments funded from the retained (capitalized) profit are unprofitable, i.e. the company bears losses, its value decreases as a direct consequence of the unprofitable nature of those investments. In theory, self-financing is the cheapest method of corporate finance, cheaper than a donation, but this is certainly more theoretical, especially since the donation is not financing; the definition of financing is the return of the money invested, in a time-frame, with the addition of a yield (Pătulea 2009, 276). The investor's gain is an expense for the financed company, and the company's best interest is 
to have the lowest financing cost. In case of self-financing, the cost is not direct, but indirect, what the investor would have done with the money he could withdraw in the form of dividends to invest in something else, at a better return. As a conclusion, self-financing is not free, but has a cost: the opportunity one. It is true that, depending on the size of company, this cost is viewed more objectively or more subjectively. The larger the company (by shareholders), the more costly it is; conversely, the smaller the company, like a partnership (or a single member company), the cost is more subjective because the shareholder is also sentimental to the company, his participation being not only an investment but also a personal business, professional satisfaction, a self-paid job, or even a way of life.

Balancing the use of internal and external financing sources, as well as the share of an external source in relation to another external source, primarily depending on the cost of financing (direct or opportunity one) is a difficult, important and complex decision. The analysis of all funding options is called financial management, and, when it comes to costs, falls primarily under the responsibility of the Chief Financial Officer. The financiers, in their turn, are interested in the gain obtained from the company and the priority rank of the financier on the assets of the company, all of which are interdependent. For example, corporate creditors have priority over shareholders, who are residual creditors (Kershaw 2012, 709), and preferential shareholders have a priority (dividend distribution and shares redemption) over ordinary shareholders. Among them, creditors only take precedence based on legal priority (privilege) and lien registered in their favor. According to Art. 2333 par. (1) of the Civil Code, a privilege is the preference given by law to a creditor considering his claim and the company cannot agree subordination among creditors, because the preference on certain assets, as in the case of privileges (Deleanu, Ion. 2002, 183), is the result of a favor granted directly by the law (Zlătescu 1970, 48).

Attracting finance is a three-step operation. The first step is to establish its size, depending on the investments to be funded, necessary for the development of company. The second step is to determine how much funding can be provided from internal sources, i.e. from the retained profits to which shareholders are willing to give up by not distributing or distributing limited dividends, because what uncovered balance is taken from an external source. The third step is the choice of the external source, i.e. the issue of new shares or the indebtedness, or a combination of them. The decision is not easy because it is necessary to analyze the direct and indirect risks and costs of each source. If these costs are considered too high, the company can re-analyze the investment plan and give up (some of the) costs that are too high that can lead to financial difficulties (Robert 1996, 191). Financing costs are quantified as the rate of return. The cost of equity financing is higher than that of debt financing (Şcheaua 2000, 85; Cărpenaru, Predoiu, David, and Piperea 2001, 446), with the rate of return being higher for equity than for debt. The reason why the return on equity financing (referred to as the "Internal Rate of Return"/IRR, that is that discount rate applied to a company as a business after an investment in the form of share capital, for which the present net value equals 0 ) is higher than the (external) rate of return on a debt finance (i.e. interest rate) is that financing in the form of equity is more risky than in the case of debt financing (total risks include the risk of the industry and, in addition to foreign investment, country risk) because creditors are preferred to shareholders in claiming the assets, according to the theory of risk and return that says the two are in a direct relationship of proportionality: the higher the risk, the higher the investor's earnings, hence the more expensive financing. It is true that the Internal Return Rate is a expectation, an investment projection and not a contractual element such as the interest rate, but equity providers such as private equity funds sometimes convert the forecasted earnings into a debt (total risks include the risk of the industry and, in addition to foreign investment, country risk) as debt investors can remain with a simple expectation at risk of insolvency, in the absence of sufficient security from the debtor. The cost of equity financing - that is, dividends and/or the capital gain obtained from the sale of shares - is strictly financial, non-deductible, while interest on debt is not only a financial cost but also an accounting one, and is fiscally deductible. However, the direct financial cost is not the only criterion in choosing the source of funding but only one of them, other indirect costs being the lien given by the company or the involvement of the investors in the 
company decision. Securing the debt with assets as a lien for the claim of the lender is an indirect cost that may occur on debt financing, while dilution (including losing the control stake) is an indirect cost associated with equity. Also, excessive debt does not only mean high direct financial costs, which reduce profit, but also increase the risk of insolvency, a risk that is absent when the company is financed through equity (Kershaw, David. 2012, 715). An interim financing option, which reduces the risk of insolvency and at the same time allows for the maintenance of decisional control, is the issue of preferred shares.

The more the company is and/or the more attractive for investors, the more varied the range of financing options and the cost structure that is heavily influenced by credit rating agencies. Conversely, a small company with little developmental prospects (know-how, patents, operating licenses, etc.) will not have access to all available sources in the market and will have to confine itself to small bank loans (Ferran 2011, 342). In all cases, there is no credit financing in any form (bank credit, leasing or debt issue) that is not influenced by the company's debt-to-equity ratio: the lower the ratio, the more borrowing space and vice-versa. Also, when indebtedness complements funding by equity or self-financing, the financial leverage effect is created and the shareholders will want their equity contributions to be as small as possible and the indebtedness the highest, to develop the business with someone else's money. The concept of "Other Peoples' Money" is in fact the fundamental principle of corporate finance, as it maximizes the most important financial ratios: Return On Equity (ROE) and Return On Assets (ROA), though at the same time it is a two-edged sword: if the debt financed investment produce the estimated returns, the company (and its shareholders) earn; if not, then borrowing costs will create financial difficulties for the company (Higgins 1996, 194). A perfect ratio of indebtedness exists only in an ideal theoretical market, so the corporate executives must find the optimum ratio in the given conditions, which implies a good knowledge of the market and its prospects. In other words, a company's decision to indebt is more than pertinent, up to a point, because the money drawn from debt has the leverage effect on shareholder money, the latter taking advantage of the fact that the money (especially those borrowed through long-term indebt such as certain bonds) are invested in wealth-generating assets that bring a higher return on their cost (interest), which increases the value of their shares (Downes, and Goodman 1995, 534).

Leveraged recapitalization takes place when the company borrows intensely (especially through bond issues) in order to distribute and pay dividends to shareholders, so that assets, economically speaking "belong" to both categories of investors (shareholders and creditors) because they secure the repayment of debt, and the company's revenues is used more to pay these debts. By distributing dividends, the value of market shares increases significantly, but the value of the company decreases due to capital outflows in the form of dividend payments and because of worsening the debt-to-equity ratio, with creditors sometimes becoming more concerned with the company than shareholders. The strategy of recapitalization through indebtedness is used by a company's management in an attempt to increase shareholders' equity, but not by increasing the value of the company but by distributing dividends (Haas 2011, 616). This method is sometimes used by the company's management to avoid a hostile takeover, sometimes comes from the shareholders' initiative.

\section{Equity contributions}

A first meaning of contribution is that of a liability arising from the subscription of shares, in the form of bringing value to the company in exchange for new issued stock that is the object of the subscription relationship (Georgescu 2002, II, 27). A second meaning is that of financial value in its materiality (Popescu 1983, 96), that is, the object of the obligation (Ionaşcu et. al. 1967, I, 208). From this point of view, contributions are in cash, in kind, in receivables and in services. They constitute the common fund (Paşcanu 1909, 485), which the shareholders exploit under the umbrella of the legal personality of the company. A special form of equity contribution, allowed by law, is the goodwill, which is considered to be an asset in itself, although it is a de facto universality. However, contributing one's assets and liabilities is not allowed, as it is a de jure universality, non-transferrable through inter-vivos acts. 
By legal regime, in this study, it is understood the situation of equity contributions (in cash, in kind and in receivables) after their transfer to the legal capital of the company. From both legal and accounting point of view, once the contribution is pain in, the amounts represented by these contributions are recorded in the balance sheet liability (Petrescu-Ercea 1939, II, 199), in the legal capital account (account no. 101) and represent the debts of the company to the shareholders born of subscription, while the amounts and assets in their materiality are recorded in the assets side of the balance sheet (in the related accounts, by their nature), together with the other assets of the company acquired in any other different ways. Besides debts to shareholders, the company also records debts to third parties arising from the various legal acts and operations of the company (loans, bonds issue, leasing, torts, etc.). Both categories of debt form together the balance sheet or the financing sources of the company, while the assets and amounts in the balance sheet represent the resources with which the company has been financed from the sources or the self-financing, the resources it uses in its economic activity.

The legal capital of the company, as stated in the articles of incorporation, need not be detailed in terms of its composition (depending on the nature of the contribution or the currency in which it is expressed), its value being sufficient; the mention appears only because the charter/amendment to the charter represents in general the instrument of the subscription relationship. However, upon its updating, made under Art. 204 par. (4) of the Companies Law no. $31 / 1990$, the mention (Ion 1999, 31) becomes not only unnecessary but also wrong because, as I said, the contributions - in their materiality (cash, goods, receivables) - were never part of the legal capital as an element of the liabilities, but as part of the asset, in the legal capital being recorded only their value, in order to quantify the company's debt to the shareholders who financed the company through equity contributions, on the basis of which they acquired shares granting them corporate rights. Once entered as corporate assets, including by means of equity contribution, the amounts, goods or receivables merge with the other amounts, goods or receivables entered into that asset side of the balance sheet in any other way and lose their individuality, the company having all rights on them, as it see fit. The Companies Law (Art. 7 letter d) and Art. 8 letter e) does not require the charter to mention the "composition of legal capital", that is, the currency of the payment, namely the nature and description of the contributed goods, but only the value and the way of valuation of the latter, and the structure of the legal capital is not its composition, but something else: its distribution among the shareholders, or, in other words, the equity participation of the shareholders in the legal capital, depending on the share of each of them.

Operationally, money, irrespective of the legal way of entering the company's balance sheet (equity contribution, loan, bank credit, payment from customers, etc.), if they exceed the ceiling, their transfer to the company is done by bank transfer. If a company has open accounts with several banks, it does not mean that each bank account is linked to an account such as the equity account; the existence of multiple accounts is motivated by the flexibility of payments to and from the company, not by an imperative legal provision (we are surprised, therefore, by the way a company was denied an petition on the grounds that certain sums were not in a "legal capital bank account"; see C. Ap. Constanţa, dec. no. 1283/com/28 June 2007. Jurindex), the court having erroneously believed that if the legal capital equity contributions were paid into the company's bank account, that is a "legal capital bank account". In fact, even in the formation, in that account, which, of course, does not have an accounting function, other amounts may be paid from a company's operation made even before the registration. If the shares issued in return for such equity contributions also include a premium, there will be a double accounting recording, namely the legal capital account (no. 101) and the premiums account (no. 104). This double entry does not change the nature of acquiring a good by way of in-kind contribution to the legal capital nor does it make the good become a "partial equity contribution", which is a wrong notion.

From a legal point of view, equity contributions become property of the company (its assets) and it dispose of them as they see fit, by spending (in the case of amounts) and selling, pledging/ mortgaging (generally for goods and receivables). Goods (assets), money, and receivables come in and out of the balance sheet by the rule of universal subrogation, the assets are depreciated and 
cashed. The subrogation operates within the assets side of the balance sheet, with no relation to its liabilities side, whether it is share or legal capital. The connection of the equity contributions with the legal capital exists only at the time of the subscription, when their value is recorded in the liabilities side of the balance sheet in order to quantify the obligation of the company towards its shareholders and to correlate it to the equity contribution made, the obligation being that of recognizing the corporate rights attached to the subscribed shares. Therefore, the equity contributions are not to be confused with their financial value, the former constituting, together with the other goods and rights entered into the company by other means than subscription, its corporate assets, while the value of the equity contributions representing debts to the shareholders resulting from the subscription of shares, and is recorded in the balance sheet liabilities side, where debts to third parties are also the result of the indebtedness of the company (loans, supplier-credit, unpaid taxes, etc.).

In order to be valid, the equity contributions must fulfill several conditions. In all cases, the contribution must be real. Sham contributions are forbidden, according to Art. 73 par. (1) letter (a) of the Companies Law, which entrusts the directors (or the executives) with checking the reality of the payments (Lefter 1996, 178). The application for the registration of a company must be accompanied by proof of payment, which means that regardless of the form of company, the contribution is mandatory for each shareholder and is the essence of the company (Dogaru, Ion and Olteanu, Edmond Gabriel and Săuleanu Lucian Bernd. 2009, IV, 871). However, the contribution must not be paid in by the shareholder who is liable for the payment of the subscribed shares, but also by a third party or another shareholder, as we are not in the presence of an obligation intuitu personae (with the exception of the contribution in services), which can only be executed by its provider (Roşu 2008, 78).

Shame contribution was defined in the doctrine as "that lacking any actual or certain value or having an insignificant value that is unlikely to lead to the increase of the common fund or to be taken into account for determining the legal capital". In another definition, shame contribution is "that contribution from which the company cannot draw any advantage directly or indirectly" (Pătulea 2009, 23). Shamming the equity contributions is fraudulent both to the other shareholders who see themselves diluted, as well as to the corporate creditors who trust in the irreducible core capital expressed by the legal capital. Examples of shame contributions would be a stock or a goodwill of a clearly insolvent company, with no liquidation value, an unsecured claim on an insolvent debtor, a worthless, intangible goods (Turcu 2009, II, 382), mortgaged goods of modest residual value, made up convertible to equity receivables, or goods purchased with amounts lent by future shareholders of the company or for which the company has guaranteed. Another example of sham is that the property that is not in legal use or it has been seized. Another variety of sham, which, however, is sanctioned distinctly by prohibiting the exercise of corporate rights, is the transfer of contributions from one company to another within the same group: the parent company increases the legal capital of the subsidiary, and subsidiary increases then the share capital of the parent company (Băcanu 1999. 73), constituting or consolidating cross-holding, for the purpose to dilute the minority shareholders rather than trick third parties, because the creditors basically do not trust in the value of the legal capital, on the one hand, and the financial statements of the companies belonging to the same group must be viewed in a consolidated manner on the other hand.

In general, the sham contribution is the result of a liability that equals or exceeds the value of the contributed good (Pătulea 2009, 24) or subject to conditions of any kind or terms. The sanction of the sham contribution is the rejection of the incorporating the company that has such contribution, respectively the rejection of the registration of the increase of the legal capital, when the sham contribution is made after the establishment. If the sham is not observed by the Trade Registry Office, the shareholders can challenge the decision of the general meeting of shareholders that approved the shamming increase of the legal capital, and the creditors can oppose to the same decision, as stipulated in Art. 61-62 of the Companies Law. Furthermore, there are specific action of civil liability against the directors in charge with checking the reality of the contributions (derivative action), grafted on Art. 73 par. (1) letter a) of the same law (also available for creditors, 
but only in case of insolvency of the company). To all this, of course, is added the criminal liability, when the conditions provided in Art. 273 letter c) and e) of the same law.

Apart from the reality, the equity contributions must also be useful to the company, and the two notions are not to be confused. If the reality of the assumption implies its palpable, concrete, unimproved existence, futility means that it is out of the interest or financial needs of the company. However, there should be no sign of equality between the scope and the object of activity, the scope exceeding the registered activity, indicated in the charter, especially in the context of the abrogation of the ultra-vires sanction for the companies. For example, a "freight and passenger transport" company based in the city of Bucharest receives as an equity contribution an immovable asset located in the town of Suceava (Lefter 1996, 178). Although the aspect is more likely to occur for in-kind contributions, the uselessness of cash contributions is not excluded. Also, the conversion of debt into equity could be used as a dilution method when there are no economic grounds for such operation. As a conclusion, has utility a contribution that produces or brings revenues at a time when the company needs them.

Irrespective of the nature of the equity contributions, they are not interest-bearing (Art. 68 of the Companies Law), in exchange for their contributions, shareholders receiving equity shares generating corporate rights. If it were otherwise, it would mean interest to be paid out of the legal capital, which would deny the idea of associating not only for profit but also for loss, making the shareholder both the beneficiary of the dividends, when there is profit, and the beneficiary of interest (creditor), when there is a loss, what cannot be (Dumitrescu, M.A. 1924, 443). Profit replaces interest, and this is the essential difference between a shareholder and a creditor (Arion 1915, II, 66). Therefore, the norm provided by Art. 68 of the Companies Law is imperative and cannot be derogated from.

The value of the shares issued for subscription in exchange for equity contributions is, generally, not the par value but a value influenced by both the relationship between the shareholders and the relationship between all the existing shareholders on the one hand, and third parties investors that want to subscribe, on the other hand, as well as the combination of the two (i.e. when not all shareholders participate in the subscription). Issue of shares at par value is rather a particular situation, when the value of the company (small size) - practically for reasons of convenience - is accepted as equal to that of the legal capital. In all other cases, the issue value of the shares is not determined by reference to the par value but as a ratio between the fair market value of the company and the total number of issued shares (in circulation). The lack of any economic link between the par value and the fair market value of the shares has been the reason why, in some legislations (like in the United States and in all Commonwealth countries, less the United Kingdom, which is (still) hold by the Companies Directive (EU) 2017/1132), the concept of legal capital and, implicitly, of par value has become practically and therefore unnecessarily useless (Căpăţînă 1996, 184).

The issue value is not directly related to the sale value of the shares by a shareholder of the company, but only indirect, in the sense that it also departs from the value of the company, but this value changes according to the size of the stake sold. The sale price is the price received by the shareholder and may be lower, higher or equal to the par value, or, more correctly, not related to the par value, but (only) with the fair market value. The determination of the issue value of the shares is a matter of internal evaluation of the company, a value proposed by the management and accepted by the shareholders, without any obligation to be mentioned in the decision of the general meeting.

Starting from corporate rights embedded in shares, what matters for a shareholder or future shareholder interested in his investment is the stake in the company's legal capital, or, in other words, the stake of the legal capital represented by his shares in the company. Every existing or potential shareholder will attempt to obtain from a subscription - whether it participates in it or not - as much of the stake of the company, according to which the amount of the corporate rights and the degree of influence of the company decision will be measured. This means that prior to subscribing to shares in the company, the subscriber (i.e. who intends either to become a shareholder or to increase or preserve his existing stake) will not negotiate the number of shares 
subscribed but the stake of the legal capital represented of those shares at the end of the subscription. The reason is that the number has only a writable importance, highlighted in the amendment to the corporate charter concluded after the increase of the legal capital, after the subscription, as opposed to the stake in the legal capital, whose importance is to establish the extent of corporate rights. Of course, we are talking about a significant stake, regardless of the type of the company, not a small percentage (like a few shares bought on the capital market).

In order to hold its stake as large as possible, the non-participating shareholder in whole or in part in a subscription will attempt to overestimate the value of the company and implicitly the price paid by the subscriber for the stake desired, on the one hand, and the subscriber will try to underestimate the same value, on the other hand. We will call these attempts, in the following, "situations of divergence". These are as follows: overvaluation will benefit (i) the shareholders who do not intend to participate in the subscription; and (ii) the participating shareholders but less than the pre-emptive right grants. Vice-versa, undervaluation will benefit: (ii) the shareholders who participate based on the pre-emptive rights, and (iii) third parties, in any circumstances (with the understanding that the Companies Law no. 31/1990 logically assimilates to third-party those shareholders that subscribe above the pre-emptive rights).

From this game, where, depending on the position of the participant in the subscription operation, one party wants to overstate the company and the other party to underestimate it, it results in its fair market value, and, implicitly, the fair market value of one share, as a ratio between the value of the company and the number of shares issued prior to subscription. As we can see, the process is similar to the one in which a vendor tries to sell his merchandise as expensively, and the customer tries to get it as cheaply as possible; in our case, the parties are (i) non-subscribing shareholders, in whole or in part, in the position of the seller, and the subscribing ones, for all the pre-emptive rights or in addition, in the position of the buyer, and the object of the contract is the stake negotiated as a fraction of the legal capital, in the position of the commodity. Of course, the starting point of these negotiations is a valuation of the company carried out by each of the parties by various assessment methods.

\section{Institutionalized credit}

Institutionalized credit is an interest-rate loan extended by a financial institution such as a bank, an investment fund, or a non-banking financial institution. In principle, the loan agreement is negotiable, but the extent to which the proportion of each party's negotiating powers varies in favor of the lender, the more the contract tends to be an adhesion. Where it exists, the bargaining is different from one debtor company to another, depending on its size, market position, financial situation, business plan, the investment it intends to finance (and) the borrowed loan, the quality the size of the borrowed amount and the lending period, the guarantees provided, the leverage capacity, the level of other sources of financing of the company, and, as a consequence, the risks to which it would be exposed the creditor would extend the credit. Some of these are found in the loan agreement (in its main content or in an annex), constituting conditions that the company fulfilled at the date of the conclusion of the agreement and which were the basis for the loan. The loan may be extended either as a maximum amount, disbursed in one installment or withdrawn periodically, as required, or in the form of an overdraft. In addition to the interest accrued on the remaining amounts to be repaid (although there are contracts, usually with non-bank financial institutions, where interest accrues to the whole of the capital), the bank may still charge certain commissions that loan agreements obscure more much or less, as they can be considered abusive clauses.

In order to minimize the risk of non-payment and to intervene when the debtor company goes to insolvency, loan agreements contain clauses whereby the latter assumes certain obligations to do and not to do, the breach of which gives the creditor the possibility to accelerate the repayment, based on Art. 1418 of the Civil Code (default), i.e. a debtor's deferral from the benefit of the term (Eilís 2011, 315). According to Art. 1417 par. (3) of the Civil Code, "Withdrawal from the benefit of the term may be demanded when, from his fault, the debtor comes to no longer satisfies a condition deemed essential by the creditor at the date of conclusion of the contract. In this case, it 
is necessary to have expressly stipulated the essential character of the condition and the possibility of the sanction of the forfeiture, and there was a legitimate interest for the creditor to regard that condition as essential."

In practice, the lending institutions resort to the following conditions that the debtor company must meet until all the amounts due are repaid or, in other words, the company maintains a certain situation throughout the existence of the funding, any modification requiring the creditor's consent: (i) there are no changes in the managerial structure of company; (ii) there is no change in (majority) shareholding; (iii) shareholders who are also key-persons (top-managers) not to sell their shares; (iv) the company does not change its core business; (v) the company does not alienate its main assets; (vi) the amounts of the financing to be used in accordance with the business plan attached to the loan agreement, and, last but not least, (vii) the financing institution may intervene in the company decision if the company no longer meets certain financial ratios (it is said that lenders' intervention in corporate governance, when the debtor approaches insolvency, means a change of place with shareholders (Armour, Cheffins, and Skeel 2002, 1722), who, being residual creditors, lose their financial interest in company). In order to see the status of these ratios, the company must provide a certain quality of the financial statements, audited by censors or financial auditors; the credit institution may not, however, condition the funding of the appointment of a particular audit firm $\left(8^{\text {th }}\right.$ EU Companies Directive, as amended and supplemented in 2014). Intervention in the company's decision may be in the form of accepting a creditor's representative on the board of directors (insider governance) or modeling the board's decisions in accordance with the instructions of a representative appointed by the credit institution, prohibiting the distribution of dividends, prohibiting the contracting of new debts or even the obligation to increase its share capital when net assets decrease significantly due to losses. These actions of the creditor are taken before the company becomes insolvent and without relying in any way on the security and even less on a vaguely illusory security such as the irreducible core capital. The debtor company also has an interest in accepting the creditor's intervention in its decision, given the sanction of acceleration of the repayment that would put the company in insolvency, but also because the financing institutions have (or should have) specialists in recovering companies with financial problems, who can come up with solutions (Klein, and Coffee 1996, 292). In this way, the creditor tries to determine the recovery of his debtor, the functioning of the company under conditions that generate positive cash flows being the best guarantee that the debt will be repaid. In the absence of fulfillment of the conditions of Art. 1147 par. (3) of the Civil Code, The creditor cannot accelerate the repayment, since the term of the loan was considered as essential not only for the financing institution, but also for the debtor. The provisions of this article also apply to cross-default clauses, that are, those clauses requiring or failing to do with a company affiliated to the debtor company (parent company, subsidiary company or sister company).

In order to minimize exposure to the debtor, financial institutions generally require that part of the financing of an investment, according to the business plan, be provided from shareholders' own sources, especially as companies that use bank loans are generally small enterprises, where the main shareholders are at the same time managers. This scheme also has the role of to keep the managers loyal to the funded project, so their involvement is maximal. Minimizing the exposure of the financing institution to the debtor can also be done by syndicating the credit, in particular by coopting some other financing institutions to take over part of the debt by way of assignment. Debtor companies can turn to refinancing when they identify a source that offers them more favorable financial terms (a lower interest rate or a longer repayment term). Refinancing does not necessarily mean the same type of source but also other types such as a bond or equity issue, ordinary or preferential (especially listed companies).

The loan agreement is governed by Art. 2158 et seq. of the Civil Code. With regard to the amounts of money, the possibility of extending loans without the need for any authorization from any regulatory body has been legally enshrined in the last article of Title VI of Law no. 161/2003 on security, currently repealed by the new Civil Code (and replaced by the latter). Currently, by enshrining the principle of "anything expressly non-forbidden is allowed", the prohibitions remain 
only to be expressly stipulated. In this case, the express prohibition is in the Emergency Ordinance no. 99/2006 regarding the credit institution and the capital adequacy, referring only to the lending from deposits.

The statute of limitation to request repayment of the loan is within three years of the maturity date, and in the case of successive loans between the same parties, a separate term of statute of limitation will begin to run for each loan. Thus, in the case of a loan disbursed in tranches, the statute of limitation term runs separately for each tranche, from the date of each disbursement. Being a onesided real contract, the effects of bilateral contracts, i.e. the exception of non-performance of the contract and its rescission, are not applicable (therefore, we consider that the provisions of Art. 20 of Law no. 190/1999 regarding the mortgaged loans, according to which, in case of non-fulfillment of the repayment obligation, the agreement is terminated, the resolutions cannot intervene, in the case of unilateral contracts, only on the basis of the joint agreement of the parties, according to Art. 1270 par. (2) of the Civil Code - mutuus consensus, mutuus dissensus - which replaced Art. 969 par. (2) of the old civil code). If, as regards the impossibility of opposing the exception for non-performance, things are obvious, with respect to the repayment the loan at the maturity date, we know that the creditor can obtain this by enforcement, together with interest at the time of repayment. Considering the unilateral character, the concluded but not disbursed loan agreement can only be qualified as a bilateral preagreement, which means that the financial institution has the obligation to extend the loan amount and the borrower's obligation to accept it. Otherwise, a party may request the rescission of the preagreement if the other party does not fulfill its contractual obligations as well as compensation (for example, the borrower, although fulfilling all the conditions to receive the loan amount, hits the refusal of the financing institution, thus causing injury). If the interest rate was aligned to the market average, the borrower would not have a financial interest in claiming compensation to the financial institution because it would call for another source of funding; but if the interest rate was an advantage, it would have the interest to do it.

The repayment of loans extended in a given currency must be repaid in the same currency, regardless of the increase or decrease of the value of the respective currency relative to other currencies (Art. 2164 of the Civil Code). However, it is considered that the monetary nominal rule does not apply if the devaluation of the reference currency took place after maturity, at which point the value difference can be obtained by the lender as compensation. The debtor companies must therefore be very careful about the currency in which they take the loan, because they assume the currency risk out of which they that can profit or they can lose. If they are exporters, then a weakened national currency is desirable for them because the costs, denominated in this currency, are lower. Conversely, if they import, a strengthened national currency will be desirable because the costs will be in the foreign currency in which the imported goods are paid. If the company sells goods or services on the domestic market, an appreciation of the national currency will favor the company because it will lower credit costs, as a devaluation of the national currency will increase the cost of the credit.

To hedge foreign exchange risk, some companies resort to option contracts on the foreign exchange market in the form of risk transactions in the opposite direction to that assumed by the contracted loan. For example, if the company has an exposure to the Euro on a loan contracted in this currency and its costs are in Romanian Lei, so it will be long on the Euro, it will create a short position to offset it so that what would lose from the long position by appreciating the Euro will recover from the short option, and will only bear the cost of the option. If the Euro depreciates, it will earn from the loan agreement but will lose an equal amount of the option plus its cost. As we can see, it is as if the company were to buy an insurance policy for foreign exchange risk, a policy whose cost is equal to the one of the option (Higgins 1996, 180).

Interest may be (i) current and (ii) penalty. The current interest is that accrued on the nonrepayable amounts owed by the debtor to the lender as the price of the capital with which it was credited, having the nature of an adjudicating debt (under the accessorium sequitur principale rule, any exception that may be raised by the debtor in relation to the principal (such as the statute of limitation) also affects interest). Therefore, current interest is also called remunerating interest. 
Penalty interest is that accrued at the due debts owed by the debtor to the lender, having the nature of compensation for non-repayment at maturity of the principal and any current interest (if capitalized). The legal nature of the penalties is that of a pre-determined compensation. Therefore, the current interest is not a compensation, but a service price consisting in the borrower making the borrowed amount (the capital) at the disposal of the borrower, only the penalty interest being a compensation. Current interest is fixed or variable. When it varies, it is linked to an external indicator such as a monetary index (IRCC, EURIBOR, LIBOR etc.) plus a margin. Interest rate variation is normal as long as the lending institution is funded from other sources, which allows it to transfer costs to the client. Therefore, a fixed rate of interest means the bearing of a monetary risk by both parties, depending on market fluctuations in interest rates. In any event, the financing institution may not change the interest rate without this being specified in the loan agreement and without the amendment being based on a calculation formula agreed by the parties that sends out verifiable ratios under the sanction of its cancellation as a clause abusive.

\section{Conclusions}

Corporate financing is an important tool that, alongside with corporate governance, assemble the corporate law. Equity and debt, as the only source of finance, should be elected or combined to form the right instrument for a company to develop. Balancing the use of internal and external financing sources, as well as the share of an external source in relation to another external source, primarily depending on many factors that makes the funding decision difficult, important and complex.

\section{References}

Arion, C.C. 1915. Commercial Law Text Book, vol. II. Bucharest: Edited by Vasile Ştefănescu.

Armour, John and Cheffins, Brian and Skeel, Jr., David A. 2002. "Corporate Ownership Structure and the Evolution of Bankuptcy Law: Lessons from the United Kingdom.” University of Pennsylvania Law School, Penn Law, Legal Scholarship Repository. January 1.

Băcanu, Ion. 1999. The Legal Capital. Bucharest: Lumina Lex Publishing House.

Căpăţînă, Octavian. 1996. Companies. $2^{\text {nd }}$ Ed. Bucharest: Lumina Lex Publishing House.

Cărpenaru, Stanciu D and Cătălin, Predoiu and David, Sorin and Piperea, Gheorghe. 2001. Companies, Regulations, doctrine, jurisprudence. Bucharest: All Beck Publishing House.

Deleanu, Ion. 2002. Parties and third parties. Relativity and opposability of legal effects. Bucharest: Rosetti Publishing House.

Dimitriu, Vasile. 1902. Commercial Law Text Book. Iași: Lithographie.

Dogaru, Ion and Olteanu, Edmond Gabriel and Săuleanu, Lucian Bernd. 2009. Basics of the Civil Law. Bucharest: C.H. Beck.

Downes, John and Goodman, Jordan Elliot. 1955. Finance \& Investment Handbook. New York: Barron's Financial Guides.

Dumitrescu, M.A. 1924. Around the balance sheet of anonymous companies. Bucharest: Companies and Commercial Law Review.

Ferran, Eilís. 2011. Principles of Corporate Finance Law. New York: Oxford University Press.

Georgescu, I.L. 2002. Romanian Commercial Law. Bucharest: All Beck Publishing House.

Haas, Jeffrey J. 2011. Corporate Finance (In a Nut Shell), $2^{\text {nd }}$ Ed. St. Paul: West.

Higgins, Robert C. 1996. Analysys for Financial Management, $6^{\text {th }}$ Ed. Boston: Irwin McGraw-Hill.

Ionaşcu, Traian et. al. 1967. Civil Law Treaty. Bucharest Romanian Academy Publishing House, Institute for Legal Research.

Kershaw, David. 2012. Company Law in Context, $2^{\text {nd }}$ Ed. Oxford: Oxford University Press.

Klein, William A. and Coffee, Jr., John C. 1996. Business Organization And Finance. New York: The Foundation Press.

Lefter, Cornelia. 1996. Limited Liability Companies - Theoretical and Practical Solutions for Entrepreneurs. Bucharest: Economic Publishing House.

Oroviceanu, Cătălin. 2010. Considerations on Art. $153^{24}$ of the Companies Law. Bucharest: Romanian Business Law Review 10.

Pașcanu, Mihail. 1909. Commercial Law Text Book. Bucharest: Edited by Const. Satmari.

Pătulea, Vasile. 2009. Financing of commercial companies. Shareholders equity, legal capital. Bucharest: Hamangiu Publishing House.

Petrescu-Ercea, Constantin. 1939. Commercial Law Text Book, edited by Ion Floriţă. Cluj: Lito Schildkraut Publishing House. 
Popa, Ioan et. al. 1997. International Commercial Transactions. Bucharest: Economic Publishing House. Popescu, Tudor R. 1983. International Trade Law. Bucharest: Didactic and Pedagogical Publishing House. Prunea, Petru. 2001. Capital Market. The Chronic of the Risk Challenge. Bucharest: Economic Publishing House. Roşu, Claudia. 2008. Agency Agreement in the Private Law. Bucharest: C.H. Beck.

Stelian, Toma. 1916. Commercial Law Text Book, $3^{\text {rd }}$ Ed. Bucharest: Edited by Mill. Ionescu Berbecaru.

Şcheaua, Marius. 2000. Companies Law no. 31/1990, commented and annotated. Bucharest: All Beck Publishing House.

Turcu, Ion. 2009. Theoretical and Practical Treaties of Commercial Law. Bucharest: C.H. Beck.

Zlătescu, Victor Dan. 1970. Creditor's guarantees. Bucharest: Romanian Academy Publishing House. 